\title{
Structural stability of the research \& development sector in European economies despite the economic crisis
}

\author{
Jutta Günther ${ }^{1}$, Maria Kristalova ${ }^{1,2}$, Udo Ludwig ${ }^{3,4}$ \\ ${ }^{1}$ University of Bremen, Germany \\ ${ }^{2}$ Friedrich-Schiller University Jena \\ ${ }^{3}$ Halle Institute for Economic Research (IWH), Germany \\ ${ }^{4}$ University of Leipzig, Germany
}

Corresponding author: Jutta Günther, University of Bremen, Email: jutta.guenther@uni-bremen.de; phone: +4942121866632

\begin{abstract}
When an external shock such as the economic crisis in 2008/2009 occurs, the interconnectedness of sectors can be affected. This paper investigates whether the R\&D sector experienced changes in its sectoral integration through the recession. Based on an input output analysis, it can be shown that the linkages of the R\&D sector with other sectors remain stable. In some countries, the inter-sectoral integration become even stronger. Policy makers can be encouraged to use public R\&D spending as a means of fiscal policy against an economic crisis.
\end{abstract}

Keywords: economic crisis, research and development, input-output-analysis

JEL classifications: C67, H12, O30, O38

Publication information: This article was published as Günther, J., Kristalova, M. \& Ludwig, U. Structural stability of the research \& development sector in European economies despite the economic crisis. J Evol Econ 29, 1415-1432 (2019), DOI:

https://doi.org/10.1007/s00191-019-00640-z 


\section{Introduction}

By the end of the year 2008, the global economy was hit by a deep economic downturn. A lack of demand caused by a loss of confidence in the future economic development was followed by negative consequences for production, employment, investment and income. Worldwide, countries suffered to a different extent, the developed countries being especially negatively affected (Fagerberg/Srholec 2016). In the OECD countries, the gross domestic product (GDP) on average declined by 4\% in the year 2009 as compared to 2008 (OECD 2012). In Figure 1 it is shown that the GDP per capita strongly declined in Finland, and relatively less in France. The other countries - Austria, Germany, and the Netherlands - lay just between and experienced similar losses. Because of the importance of technological progress for the future growth of R\&D intensive economies, Austria, Germany, Finland, France and the Netherlands are selected here as examlates countries, that used $R \& D$ subsidies as a means of stabilization in the economic crisis (OECD 2009).

Figure 1: GDP per capita in purchasing power parities at constant 2011 international $\$$ in selected European economies 2000 to 2015

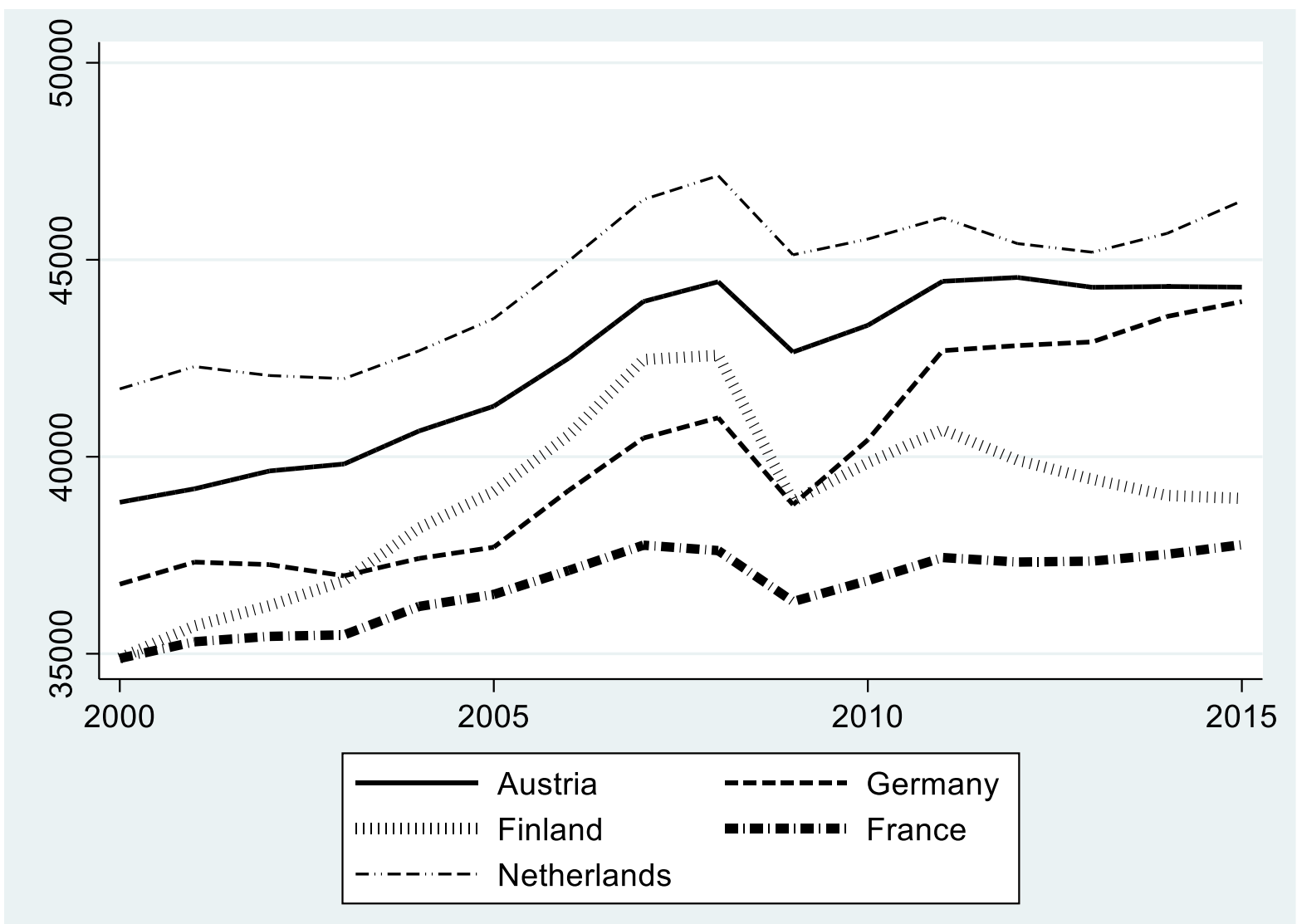

Source: World Bank, own depiction.

In the course of the crisis, the demand for consumer and capital goods declined sharply. Negative expectations also caused a downturn of R\&D activity. Archibugi and Filippetti (2011) show that, in the aggregate, most of the European economies experienced an overall slowdown 
of R\&D spending by private firms. ${ }^{1}$ However, micro level empirical studies reveal heterogeneous behavior of firms with respect to $R \& D$ spending. Despite the economic crisis, some particular groups of firms, among them the large and established as well as the young and dynamic firms, continued their R\&D investments or even increased the budget for $R \& D$ (Archibugi/Filippetti/Frenz 2013a, 2013b). Kang/Baek/Lee (2017) in a recent empirical study highlight the fact that firms with a high technological capability maintain R\&D spending under a negative shock, and firms with a low technological capability decrease R\&D spending.

At the country level, the private sector in France slightly increased R\&D spending (see Figure 2 ) in the year 2009 as compared to 2008 . However, the overall decrease of private R\&D spending has been assessed as a challenge for technological competitiveness. According to Archibugi/Filippetti (2012), the peripheral European economies were negatively affected with respect to their technological catching-up process. If this development cannot be revised, it will have lastingly negative consequences, especially for these countries. Today, the R\&D spending per head in European economies is quite heterogeneous as shown in Figure 2.

Figure 2: R\&D spending of the business enterprise sector in Euro per head in selected European economies 2005 to 2015

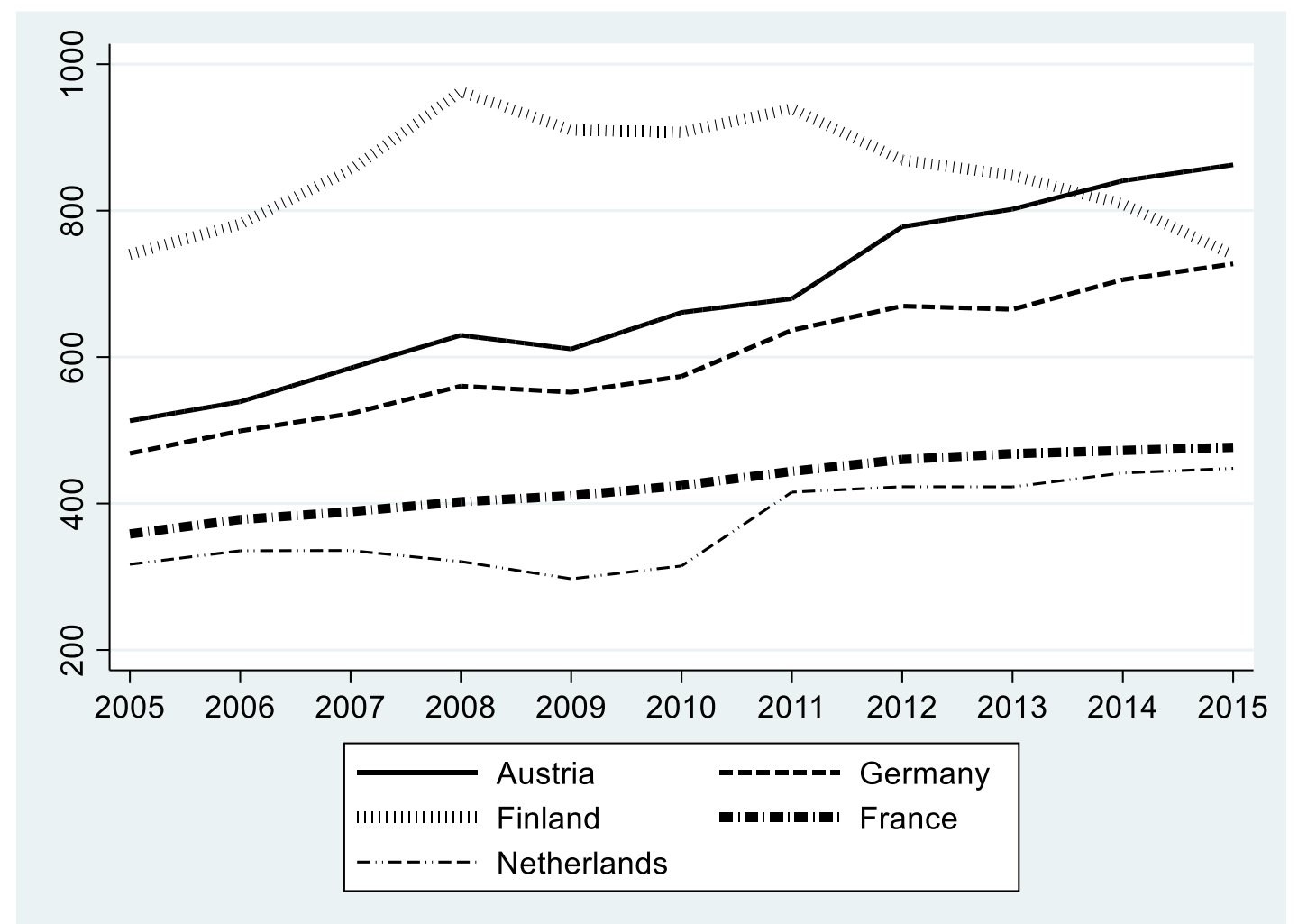

Source: Eurostat, own depiction.

As a reaction to the severe economic crisis, most governments around the world introduced fiscal policy programs to stabilize the demand side of the economy. Fiscal policy programs typically consist of different public spending tools, such as corporate tax relief, public spending for physical infrastructure, or consumption vouchers, income tax reduction, etc. Several

\footnotetext{
${ }^{1}$ This empirical observation is in line with theoretical findings from Aghion et al. (2012), Shleifer (1986) and Barlevy (2007). However, cyclicality of R\&D will not be the focus of this paper.
} 
countries also introduced an additional subsidization of research and development (R\&D) for private, especially small and medium sized firms (OECD 2009).

From a theoretical perspective, it is widely acknowledged that R\&D investments contribute to growth through product or process innovation, and that technology spillovers are essential for long run economic development (Grossman/Helpman 1992). This is, however, not what we are focusing on in this paper. We rather refer to the $R \& D$ sector because governments in the $R \& D$ intensive countries used $R \& D$ subsidies as a means to counteract the economic crisis in the short run and through the demand of production factors. The R\&D subsidies unfold their stabilization effect dependent on their sectoral interconnectedness in the economy as a whole (backward multiplier effects). In this respect, we are interested in whether the external shock of the economic crisis has affected the impact of the R\&D sector on the total economy. The paper will use backward multipliers as an indicator for the R\&D sector's structural interconnectedness.

As the crisis appeared to be a unique episode, little evidence can be found in the literature so far about the reaction of the R\&D sector to such an event. This is where the paper ties in. We will investigate whether and how the R\&D sector in selected European economies changed its structural interconnectedness under conditions of crisis. Insights of this paper will serve policy makers with respect to the question whether and in which direction an economic downturn influences the $R \& D$ sector and thus short term macroeconomic effects of $R \& D$ funding.

The paper will be structured as follows: In section 2, the conceptual framework will be presented, starting with a literature review (2.1) from which the contribution and subject of analysis will be derived (2.2), followed by an introduction into the research method and data base (2.3). Afterwards, in section 3, the empirical results will be provided. Section 4 will draw conclusions, discuss further research and give policy recommendations.

\section{Conceptual framework}

\subsection{Literature review}

The impact of R\&D investment on productivity has long been subject to empirical analyses from both a macro and micro perspective. Many macroeconomic studies focus on technology spillovers deriving from private R\&D investment (e.g. Bayoumia et al. 1999, Kancs and Silverstovs 2016, Sun et al. 2016). On the other hand, microeconomic studies deal with the impact of public R\&D subsidies on firm's research and innovation behavior (e.g. Alecke et al. 2012, Schwartz et al. 2012). Beneficiaries of R\&D subsidies are often small and medium companies with innovative ideas but with a lack of sufficient internal resources. While most microeconomic analyses identify overall positive effects of R\&D spending, the insights about possible crowding out effects through subsidization remain mixed (David et al. 2000). These studies focus on long run productivity growth and are supply side oriented.

Public support of R\&D during the economic crisis followed a different rationale. Policy makers first of all intended to counteract the sudden loss of effective demand and, in the course of this, the strongly declining R\&D investments. As mentioned above, policy makers decided for additional $R \& D$ spending in favor of a short term stabilization of production and employment. 
R\&D spending during the economic crisis served first of all a demand stimulation, encouraging firms to continue $R \& D$ projects in times of strong uncertainty.

Overall, empirical analyses about the impact of public R\&D subsidies during the economic crisis are very rare so far. This is, of course, a result of the fact that such a severe economic downturn had not happed for decades. Only few studies exist that shed light on the subject from a macro or micro economic perspective.

For Germany, Hud/Hussinger (2015) investigate the mobilization effect of R\&D subsidies within a microeconometric study. They find that subsidies stimulate R\&D activity positively in small and medium firms, but in the year 2010 the subsidy effect was still smaller than in the pre-crisis year. Aristei et al. (2015) using unique firm level data show in a microeconomic study for a number of European economies that there is no full crowding out of private R\&D through subsidies, but also no addition of R\&D subsidies during the economic crisis in the late 2000 s. However, they conclude that public R\&D spending counteracted the general trend of firms' withdrawal from $R \& D$ activities.

In an ex-ante evaluation of public R\&D spending during the economic crisis, Brautzsch et al. (2015) show that public R\&D spending in Germany as a part of fiscal policy with a total primary impulse of 3.7 billion Euro rescued 0.5\% of the GDP in the year 2009. Multipliers of R\&D spending accounted for around 2.0 for output, value added, and employment, which the study values as a substantial leverage effect. The stabilization effects met policy makers' goals in the crisis year 2009, but in 2010, when the economy recovered, fiscal policy programs already worked cyclically. This analysis allowed them to simulate the concrete production, value added, income and employment effects in a large and research intensive European economy, and it analyzes the difficulty of timing of anti-cyclical policies.

If we refer to an input-output analysis as a methodical technique to evaluate stabilization and other policy programs, much more has been published, for example, during the economic recession in Germany in the year 1967 (e.g. DIW 1967, Reyher 1967) or in the context of business cycle programs during the 1970s (e.g. Spitznagel 1976). More recent studies that employ an input-output analysis to investigate business cycle effects relate to public investments in ecological construction in Germany (Kuckshinrichs et al. 2010) or broadband technology in the USA (Katz et al. 2009). Brautzsch et al. 2009 analyze the production and employment effects of the entire fiscal policy programs used during the 2008/2009 economic crisis. Internationally, an input output framework has been used, for example, in analyzing the impact of public spending during the economic crisis in China (He et al. 2009, Yuan et al. 2010). Gramke et al. (2009) use an input output framework to detect the most relevant sectors for stimulus programs. All this demonstrates the high importance of the input output analysis as a method within the context of the economic crisis literature.To sum up, the empirical literature in the sense of evaluation studies shows the suitability of input-output analyses, on the one hand, and the positive effects of subsidized R\&D spending of the private sector during the economic crisis, on the other hand. However, Brautzsch et al. (2015) show that, in Germany, R\&D multipliers were slightly smaller in the year after the economic crisis as compared to the crisis year 2009. According to Hud/Hussinger (2015), positive effects of R\&D subsidies were also smaller at micro level in the year after the crisis. These findings point to the question whether the external shock of the crisis affected the sectoral interrelatedness of the R\&D sector in the economy. It calls for an empirical investigation about the R\&D sector's interconnectedness during an economic crisis. Will the interconnectedness of the R\&D sector 
change substantially or remain stable in the face of a strong economic downturn? To answer this question, a proper description is crucial to conduct an empirical analysis. This has not been addressed in the literature so far, but it is important to understand the influence of the reaction of the R\&D sector under conditions of an economic crisis, especially on the total economy with respect to stabilization policy.

\subsection{Subject and framework of analysis}

To specify the subject and frame the analysis, one should pay attention to the R\&D sector and its structural reaction to the crisis itself (internal technological architecture) as well as to the R\&D sector's integration and impact on the total economy.

In general, we expect that, under conditions of a strong economic downturn, all economic activities slow down because of the crisis shock. Research and development, however, is not the same as general production activity in a firm. It is strategic and long term oriented, and, at the same time, the R\&D sector in terms of supplier relations for intermediate goods is part of the entire economy. A profound knowledge about the reaction of the R\&D sector with respect to its sectoral interrelation does not exist. Still, it is valuable to know when policy makers use $\mathrm{R} \& \mathrm{D}$ as a tool of fiscal policy in reaction to a strong recession. Arguing from a Schumpeterian perspective, the crisis may have encouraged the R\&D sector to change its internal technological architecture in search of new ways to satisfy its needs and improve performance. As it has been put forward by Schumpeter (1911) and been shown in some recent empirical studies (Archibugi/Filippetti/Frenz 2013a, 2013b), the economic recession can be a trigger of change and a fertile ground for innovative changes. For the context of our investigation, the supposition is that the $R \& D$ sector changed its internal production technology in the sense of new combinations of inputs. This would result in changing quantities and qualities of inputs in order to generate $R \& D$ outputs. In other words, $R \& D$ as a corporate activity itself becomes subject to innovation.

A major motivation of our analysis has been the fact that subsidized R\&D spending was used in a number of European countries to counteract the economic crisis. Thereby, the economic stabilization through backward multiplier effects from R\&D spending is central. The size of the effect, which is not subject to our study here, depends on the composition of direct and indirect supplies of intermediate goods used in the R\&D sector. Therefore, we pay attention to the sectoral relations of the $R \& D$ activity under conditions of the economic crisis.

From the economic literature we know that every severe economic downturn typically leads to cost reduction behavior because of the loss of sales and profits, uncertainty and risk aversion behavior. This holds true not only for manufacturing but also for business R\&D activities. Reasons for this are a lack of cash flow (Harhoff 1998, Rafferty/Funk 2004) and diminishing perspectives on the sale of new products (Devinney 1990, Shleifer 1986, Barlevy 2007). Financing of R\&D and innovation has always been a difficulty, especially for small and medium firms. Hall et al. (2016) discuss the financing constraints of physical R\&D investment, which has become more difficult during and after the crisis. However, fin our context - the structural linkages of the R\&D sector - it is important to keep in mind that established supplier relations often cannot be terminated right away. Contractual as well as practical reasons given by established processes and routines often counteract rapid changes, especially in the area of research and innovation. 
In the context of general economic behavior, it could also be assumed that the R\&D sector reacts with a withdrawal from international sourcing and a possible substitution behavior between domestic and imported supplies. This would correspond to the fact that an economic downturn is typically related to a weakening of international trade and foreign economic relations in general (e.g. Freund 2009, Bems et al. 2013). Shrinking import and export activities could be observed in Europe during the 2008/2009 crisis (e.g. Eaton et al. 2010). Whether the crisis related trend of de-globalization bled through in the R\&D sector is, however, not entirely certain. Similar to the aforementioned case with intermediate purchases in general, the withdrawal might be limited because of binding international supplier contracts, and the domestic substitution of imports usually takes time (Hirschman 1968, Levchenko et al. 2010).

Overall, we must keep in mind that, from the Schumpeterian perspective, the R\&D sector is different from any other production sector of the economy, but at the same time closely embedded in the entire economy with respect to supplier relations. Because of its particularities and long-term orientation as described above, our overall hypothesis is that there is a structural adjustment inside the R\&D sector but an overall stability in the R\&D sector's strength of embeddedness and impact on the economy when using R\&D as a means to counteract an economic downturn. However, there might be differences between countries depending on the specific reaction of the $R \& D$ sector.

The question of sectoral stability will be investigated empirically, first through an analysis of input coefficients as a proxy for production technology (Ten Raa 2007, Östblom 1992, Kraines/Yoshida 2004) $)^{2}$. This will reveal possible changes of the internal technological architecture. Then, we will look at the size of backward multipliers and a measure of sectoral dispersion. We will also pay attention to the ratio between backward multipliers based on "domestic production and imports" and those based on "domestic production". All this involves a comparison across time, i.e. before, during and after the crisis, for each of the five countries.

\subsection{Research method and data}

The analytical framework of this paper is based on an input-output analysis. This allows us to capture the technology of production processes by sectors, direct as well as indirect supplier relations. Input coefficients, backward multipliers, and indicators derived from them will be used in the empirical study.

\section{Input-Output model}

To calculate backward multipliers of R\&D spending, which serve as a fundamental indicator in our analysis, the static open input-output model is applied.

At first the vector of a sectoral output $\mathbf{x}$ is calculated by multiplying the inverse Leontief matrix $(\mathbf{I}-\mathbf{A})^{-1}$ of inputs with the vector $\mathbf{y}$. The latter vector represents the final output of the open economic system ${ }^{3}$. Additional variables, such as value added and household earnings, are

\footnotetext{
${ }^{2}$ We acknowledge the critique of Richter (1995) who draws attention to the fact that technology is not fully expressed through input coefficients. We use input coefficients as a proxy here.

${ }^{3}$ In our case, it is a standardized vector for all countries with all zero elements except for one billion euro in the R\&D sector.
} 
calculated using the output vector. E.g. the value added by sector va is derived from the output $\mathbf{x}$ multiplied entry-wise by the share of value added to total output by sectors $\mathbf{v}{ }^{4}$

The sectoral interrelatedness of output and value added can be decomposed into the direct effects $^{5}$ and indirect effects. The direct effect in our analysis is the primary impulse of one billion Euro and the indirect effects are the effects along the value chain (sectors linked to the R\&D sector as suppliers). The relation between the total effect and the direct effect (quotient) is called the multiplier, which measures the total interrelatedness of the final output (demand) of the system on all sectors of the economy. The equation within an open static input-output model appears as:

$\mathrm{x}=(\mathrm{I}-\mathrm{A})^{-1} * \mathrm{y}$

and the output multiplier is calculated as follows

$M(x)=i^{*} x / i^{*} y$

$\begin{array}{ll}\text { A } & \text { matrix of the input coefficients } \\ \text { I } & \text { identity matrix } \\ (\mathbf{I}-\mathbf{A})^{-\mathbf{1}} & \text { Leontief inverse of the input coefficients } \\ \mathbf{x} & \text { vector of total output by sectors (measured in million Euros) } \\ \mathbf{y} & \text { exogenous vector of final demand by sectors (measured in million Euros) } \\ \mathbf{i}^{\prime} & \text { row unit vector of the same dimension as } \mathrm{x} \text { and y vectors } \\ \mathbf{M ( x )} & \text { output multiplier }\end{array}$

The empirical core of the input-output analysis is the input-output table (IOT), which is a part of national accounts. It comprises four quadrants, of which the two first are the most relevant for our analysis. The columns of the matrix in the first quadrant represent the input output relationship. Input coefficients capture the interconnectedness of the sectors. The second quadrant shows the final demand, which comprises consumption, investment, and exports.

Until 2010, R\&D in input output tables was treated as an intermediate good used up in the production process. Due to its investment nature and cumulativeness, R\&D expenditures were recently redefined as an investment within the European System of Accounts (ESA 2010) (Eurostat 2013). This allows us to model a change of the R\&D stock as an exogenous change in final demand (investment). Through this primary effect, a chain reaction is triggered: not only sectors, which receive an additional demand, are directly affected, but also their suppliers, and suppliers of the suppliers, etc. This impact is captured through the indirect effect.

\section{Database}

Our analysis is very dependent on exactly comparable input-output tables across time and countries. Given the frequent revisions of national accounts and with it input-output tables, the

\footnotetext{
${ }^{4}$ The multipliers for value added will be presented in the appendix.

${ }^{5}$ In our case, it is one billion Euro invested directly into the R\&D sector as a standardized figure for all calculations.
} 
availability of input output tables is limited. National input-output tables for the years 2008 to 2010, used for the calculations, are available in accordance with the methodological framework ESA 1995 for the years 2008 until 2010 and were revised in the year 2011. In order to calculate backward multipliers for the R\&D sector and derive structural indicators, we use this type of table. ${ }^{6}$ These input-output tables were taken from Eurostat statistics. They are harmonized and thus comparable exactly for the period under investigation (the years before, during, and after the crisis). ${ }^{7}$.

In chapter 3, we will run the analysis for five European countries that had a substantial R\&D intensity, used public R\&D spending in their fiscal policy programs and for which a harmonized data base is available: Austria, Finland, France, Germany, and the Netherlands. The provision of harmonized input-output tables is still a challenge and subject to further development. Being able to use input-output tables for the years 2008-2010, we already go beyond the empirical analysis of the effects of R\&D spending carried out earlier by Brautzsch et al. (2015) who used input-output tables for the year 2007.

An alternative database would have been the "World Input Output Database" (WIOD), which covers more years since 2000 and many countries. But WIOD relies on an industry by industry classification while the tables from Eurostat use a commodity by commodity classification. The latter is much more suitable when analyzing the R\&D sector, because it covers not only specialized establishments carrying out mainly R\&D activities, but also all R\&D activities, including those run by enterprises as a secondary activity. ${ }^{8}$ Thus, we use input-output tables from Eurostat to calculate output multipliers on the base of the Leontief-Inverse in order to capture the direct and indirect impact of the spending for R\&D on the total economy. As will be shown in chapter 3, we use input coefficients for "domestic production and imports" as well as for "domestic production".

\section{Results}

The first step of the empirical investigation is a look at the production technology based on an analysis of input coefficients. This will be followed by the presentation of backward multipliers of R\&D investment across time and countries and an index that detects the structural position of R\&D in the economy.

\subsection{Changes in the internal technological architecture of the $R \& D$ sector}

In a first step, we scrutinize possible changes in the production technology of the R\&D sector by focusing on the purchases of inputs of the sector and analyse changes of input coefficients in the crisis year. The shares of intermediate inputs in Table 1 reflect the dependence of the output by the use of intermediate inputs and, as the complement, also the share of value added. They also signal the different level of connectedness of the R\&D sector with the total economy by countries. In France, R\&D seems to be more integrated than in most other countries, while

\footnotetext{
${ }^{6}$ In the current ESA 2010 only input-output tables for several countries for the year 2010 are available.

${ }^{7}$ Input-output tables before 2008 and after 2010 are not comparable. Therefore, we cannot extend the time period.

${ }^{8}$ A comparison of multipliers calculated for the three years and five countries by the use of Eurostat and WIOD database shows that - due to different levels of sectoral dis-aggregation (number of sectors) - there are differences not only in the size, but also in the direction of changes of backward multipliers.
} 
in Finland it weaker. The data also show that the level of $R \& D$ integration in France is even higher than the average.

Overall, in the majority of countries the R\&D sector was hit less by the crises than the rest of the economy. The output of $R \& D$ even grew in the top year of the recession 2009 in the case of Austria, Finland and France or fell less in Germany compared to the overall downturn. However, the percentage share of intermediate inputs in output changed marginally, except for Germany. There it went from $46 \%$ to $42 \%$, which means a decrease of about $10 \%$ whereas the changes in the other countries remained within the interval of $-3 \%$ and $+3 \%$. If we look at the value added - the counterpart of intermediate inputs in the output - we of course observe opposite positive or negative changes of its share in the R\&D sector. At the same time in the economy as a whole, value added in absolute terms decreased strongly. This declining value added in the total economy is mostly due to a shrinking operating surplus in all countries under review.

Table 1: Share of intermediate inputs in output for the R\&D sector and the total economy

\begin{tabular}{|l|c|c|c|c|c|c|}
\hline & \multicolumn{2}{|l|}{ R\&D sector } & \multicolumn{2}{l|}{ Total economy } & \multirow{2}{*}{2010} \\
& 2008 & 2009 & 2010 & 2008 & 2009 & \\
\hline Germany & 0.46 & 0.42 & 0.43 & 0.53 & 0.52 & 0.52 \\
\hline France & 0.60 & 0.59 & 0.59 & 0.51 & 0.49 & 0.50 \\
\hline Austria & 0.46 & 0.48 & 0.52 & 0.53 & 0.52 & 0.53 \\
\hline Netherlands & 0.47 & 0.48 & 0.48 & 0.54 & 0.53 & 0.54 \\
\hline Finland & 0.39 & 0.38 & 0.39 & 0.56 & 0.55 & 0.56 \\
\hline
\end{tabular}

Source: Eurostat Input-Output Tables, own calculations.

If we look at the structural composition of inputs of the R\&D sector, in all five countries, the R\&D sector itself is by far the most important supplier out of 65 possible supply sectors. However, $R \& D$ as an input for R\&D decreased in all countries except Austria and France in 2009. Looking at second and third important supplier sectors for $R \& D$, the picture gets more heterogeneous. Often, other service sectors dominate, such as "educational services" (Netherlands), "architectural and engineering services; technical testing and analysis services" (Germany), "computer programming, consultancy and related services; information services" (Germany), "employment services" (Austria), "chemicals and chemical products" (Austria, Netherlands).

The many single changes of all directly supplying sectors cannot be looked at individually. Therefore, we sum up the changes over all supplying sectors and calculate the difference to the previous year. Above we have reported simple differences and can tell whether countries increased or decreased inputs in the crisis year, i.e. the direction of changes.

Since the input of intermediate goods can shift into a positive or negative direction, changes of single inputs may compensate in the aggregate and possibly "disappear". In order to observe technological changes independently of the direction, absolute values of changes must be taken into consideration (see Box 1). 
Box 1: Calculation of the technical change index

$$
T C_{R \& D}=\frac{\sum_{i}\left|\left(a_{i j}\right)_{t}-\left(a_{i j}\right)_{t-1}\right|}{\sum_{i}\left(a_{i j}\right)_{t-1}}
$$

The technological change index (TC) measures the magnitude of input changes in $R \& D$, i.e shows whether technological changes take place in the sector R\&D and to what extent.

Table 2 presents the technological change index (absolute changes in \%) for the five countries over time. The index captures the changes of input coefficients in absolute values that took place in all sectors that directly supply the $R \& D$ sector. The higher the figure, the stronger the overall technological change.

Table 2: Technological change index - absolute changes (\%) of input coefficients across all sectors supplying the R\&D sector as compared to the previous year

\begin{tabular}{|c|c|c|c|c|c|c|}
\hline & \multicolumn{3}{|c|}{ Domestic Production \& Imports } & \multicolumn{3}{|c|}{ Domestic Production } \\
\hline & 2009 & 2010 & 2010 to 2008 & 2009 & 2010 & 2010 to 2008 \\
\hline Germany & 16.3 & 7.6 & 18.5 & 17.5 & 7.9 & 20.8 \\
\hline France & 5.3 & 2.4 & 5.7 & 6.9 & 2.9 & 7.2 \\
\hline Austria & 14.2 & 16.0 & 23.7 & 23.5 & 28.8 & 40.3 \\
\hline Netherlands & 6.4 & 2.5 & 4.8 & 11.8 & 7.9 & 5.7 \\
\hline Finland & 17.3 & 16.9 & 21.8 & 14.2 & 19.7 & 23.5 \\
\hline
\end{tabular}

Source: Eurostat Input-Output Tables, own calculations.

It shows that France and the Netherlands exhibit relatively stable input structures where the absolute changes mostly remain below $10 \%$, i.e. the R\&D sectors did not change their technology to a large degree. This is different in the other countries. For Germany, we find technological changes in the crisis year, and also in Finland and Austria, there is no technological stability in the R\&D sector.

\subsection{Size and trend of backward multipliers of $R \& D$}

We first look at the size and development of output multipliers for domestic production in Table 3. The figures indicate the factor by which domestic production (output) is increased along the entire value added chain when the R\&D sector spends one unit on domestic inputs.

In most countries, the multipliers remained relatively stable over time. Only in Germany, did the multiplier decrease in the year of the crisis and failed to reach the 2008 level even in 2010. This trend indicates a small loss of integration of the R\&D sector in the domestic production of 
Germany. In France the multiplier slightly increased in 2009 and stayed stable in 2010. This signals a stability of integration.

Further, we can observe in Table 4 that, in the larger economies (France, Germany), domestic production linkages are deeper than in smaller economies (Austria, Finland, the Netherlands). This is, however, not surprising since larger countries place greater reliance on domestic sources than do smaller economies.

Table 3: Output multipliers of the R\&D sector for "domestic production"

\begin{tabular}{|l|c|c|c|}
\hline & 2008 & 2009 & 2010 \\
\hline Germany & 1.58 & 1.53 & 1.54 \\
\hline France & 1.86 & 1.88 & 1.88 \\
\hline Austria & 1.42 & 1.41 & 1.45 \\
\hline Netherlands & 1.27 & 1.28 & 1.27 \\
\hline Finland & 1.42 & 1.43 & 1.44 \\
\hline
\end{tabular}

Source: Eurostat Input-Output Tables, own calculations.

In the next step, we look at the technologically determined multipliers of R\&D before, during, and after the crisis, i.e. multipliers for "domestic production and imports" (Table 4). They capture the entire input structure of the R\&D sector and thus express the production technology of R\&D over time. Table 3 demonstrates that the strength of the production linkages of the R\&D sector across countries is very different. It shows that, in Finland and Germany, the technological multipliers are clearly smaller than in France, the Netherlands, and Austria. Although the changes over time are small, the multipliers reveal different tendencies. Compared with Table 1 they signal for Germany, France and Finland a slight withdrawal from international sourcing, while for the Netherlands, growing purchases of inputs abroad.

Relatively constant technological multipliers as shown here compensate structural changes inside and outside the R\&D sector. That's why R\&D multipliers are affected not only by changes in the direct input structure as shown above but also by changes that occur in the sectors indirectly linked to $R \& D$, i.e. $R \& D$ multipliers depend on sectoral linkages throughout all other sectors. Especially the indirect linkages of the supply chain impact the size of the R\&D multipliers. Negative and positive effects of the changes might prevail or compensate. They are all captured in the multipliers presented here.

Table 4: Output multipliers of the R\&D sector for "domestic production and imports"

\begin{tabular}{|l|c|c|c|}
\hline & 2008 & 2009 & 2010 \\
\hline Germany & 1.79 & 1.71 & 1.75 \\
\hline France & 2.24 & 2.22 & 2.26 \\
\hline Austria & 1.95 & 1.96 & 2.07 \\
\hline Netherlands & 2.03 & 2.06 & 2.06 \\
\hline Finland & 1.75 & 1.72 & 1.75 \\
\hline
\end{tabular}

Source: Eurostat Input-Output Tables, own calculations. 
So far, we interpret the changes in the size of multipliers as rather small. Since the empirical literature does not offer a criterion, we provisionally create a reference by calculating $R \& D$ multipliers using the above mentioned WIOD database. Although WIOD is less suitable for the central objective of our study - structural relationships of the R\&D activity - it can be used generally to check the size of annual changes of backward multipliers over a long time period and for years far away from the crisis. The figures in Table 5 below can be used as a reference for interpreting the size of fluctuation of multipliers presented in the core analysis. The result supports our argument of stability with regard to the level of multipliers. The differences from year to year are mostly below $1 \%$ in all countries.

Table 5: R\&D multipliers calculated as a reference on the basis of WIOD (domestic production \& imports)

\begin{tabular}{|l|l|l|l|l|l|l|}
\hline & 2000 & 2001 & 2002 & 2003 & 2004 & 2005 \\
\hline Germany & 1,56 & 1,57 & 1,55 & 1,55 & 1,57 & 1,59 \\
\hline France & 1,79 & 1,87 & 1,86 & 1,85 & 1,86 & 1,87 \\
\hline Austria & 1,80 & 1,83 & 1,81 & 1,74 & 1,81 & 1,82 \\
\hline Netherlands & 1,91 & 1,91 & 1,90 & 1,89 & 1,89 & 1,90 \\
\hline Finland & 1,46 & 1,52 & 1,52 & 1,49 & 1,49 & 1,51 \\
\hline
\end{tabular}

Source: WIOD database (release 2016), own calculations.

Before turning to more targeted indicators, a brief insight should be given about the relative position of R\&D multipliers. Therefore, we compare them with multipliers for the economy as a whole in Table 6 . This shows that multipliers for R\&D are normally smaller than the average (values below 1.0). This has to do with the intensity of backward linkages, which are in the majority of countries stronger if all sectors are taken into account. Only France strikes out, where multipliers of the R\&D sector are clearly higher than in the economy as a whole.

Table 6: Multipliers for R\&D relative to multipliers for the economy as a whole ("domestic production and import")

\begin{tabular}{|l|c|c|c|}
\hline & 2008 & 2009 & 2010 \\
\hline Germany & 0.81 & 0.81 & 0.81 \\
\hline France & 1.07 & 1.07 & 1.07 \\
\hline Austria & 0.85 & 0.88 & 0.90 \\
\hline Netherlands & 0.89 & 0.91 & 0.89 \\
\hline Finland & 0.76 & 0.77 & 0.76 \\
\hline
\end{tabular}

Source: Eurostat Input-Output Tables, own calculations.

To check for robustness, we also look at R\&D multipliers for gross value added and income (see Annex 1). We observe in all countries a very similar trend throughout the observation period (2008-2010). This holds true for "domestic production and imports" as well as for "domestic production". Thus, we will continue to focus on the output multipliers in the analyses that follow. 
To analyze a possible substitution of international sourcing, we look at the ratio between multipliers for "domestic production and imports" and "domestic production" over the three years (Table 7). If the value declines, we interpret this as a withdrawal from imported intermediate goods.

The Netherlands strike out with a generally high ratio value due to their stronger dependence on imported inputs. In Germany, the R\&D sector depends less on imported inputs. If we look at the crisis year 2009 as compared to the year 2008, we observe a small withdrawal from imported inputs in Germany, France, and Finland (declining ratio values), while Austria and the Netherlands slightly increased imported intermediate goods for R\&D. Obviously, countries react differently to the crisis in terms of their global integration, but the changes remain small.

Table 7: R\&D multipliers for "domestic production and imports" relative to multipliers for "domestic production"

\begin{tabular}{|l|c|c|c|}
\hline & 2008 & 2009 & 2010 \\
\hline Germany & 1.13 & 1.12 & 1.13 \\
\hline France & 1.20 & 1.18 & 1.20 \\
\hline Austria & 1.37 & 1.39 & 1.42 \\
\hline Netherlands & 1.60 & 1.61 & 1.62 \\
\hline Finland & 1.23 & 1.21 & 1.21 \\
\hline
\end{tabular}

Source: Eurostat Input-Output Tables, own calculations.

\subsection{Sectoral position of the $R \& D$ sector}

So far, we observe relatively stable backward multipliers in different countries and years as well as differences to multipliers for the economy as a whole. This gives a first impression about backward integration or disintegration over time. Higher multipliers indicate stronger linkages, and vice versa. But multipliers only give a first insight. They can take any value and are not a standardized indicator. A more targeted indicator frequently used in the literature (e.g. Andreosso-O'Callaghan/Yue 2004, Kumar/Das 2015) is the Rasmussen Index (Rasmussen 1956), which measures the dispersion of backward linkages of one sector in comparison to all other sectors in the economy. A value of the Rasmussen Index of 1.0 expresses an average dispersion, while a value above (below) 1.0 means a dispersion of linkages above (below) average. The index can be interpreted as a relative measure of the importance of a sector as a "demander" for the rest of the economy. 
Box 2: Calculation of the Rasmussen Index

$$
R I=\frac{\frac{1}{n} \sum_{i} \boldsymbol{c}_{\boldsymbol{i j}}}{\frac{1}{n^{2}} \sum_{i j} \boldsymbol{c}_{\boldsymbol{i j}}}
$$

The Rasmussen Index is a "power of dispersion" index, where $\boldsymbol{n}$ represents the number of sectors, and $\boldsymbol{c}_{\boldsymbol{i} \boldsymbol{j}}$ is an element of the Leontief inverse $(\boldsymbol{I}-\boldsymbol{A})^{\mathbf{- 1}}$. Therefore, the numerator stands for the sector's backward linkage and the denominator represents the average of all elements of the Leontief inverse, which makes it possible to identify whether a sector has above (stronger) or below (weaker) backward linkages, since the average value of the Rasmussen Index lies at one.

Table 8: Rasmussen Index for the R\&D sector for "domestic production and import" and "domestic production"

\begin{tabular}{|c|c|c|c|c|c|c|}
\hline & \multicolumn{3}{|c|}{ Domestic production and imports } & \multicolumn{3}{|c|}{ Domestic production } \\
\hline & 2008 & 2009 & 2010 & 2008 & 2009 & 2010 \\
\hline Germany & 0.68 & 0.68 & 0.67 & 0.73 & 0.71 & 0.71 \\
\hline France & 1.08 & 1.18 & 1.15 & 1.04 & 1.09 & 1.06 \\
\hline Austria & 0.69 & 0.78 & 0.76 & 0.71 & 0.73 & 0.76 \\
\hline Netherlands & 1.01 & 1.03 & 1.02 & 0.69 & 0.69 & 0.69 \\
\hline Finland & 0.81 & 0.85 & 0.88 & 0.62 & 0.62 & 0.63 \\
\hline
\end{tabular}

Source: Eurostat Input-Output Tables, own calculations.

Table 8 shows that the Rasmussen Index takes values above 1.0 in France in all years with an increase in the crisis year, and this applies to "domestic production and import" as well as to "domestic production". The relatively high Rasmussen Index corresponds to the finding that, in France, multipliers are higher for the R\&D sector than for the economy as a whole (see above). In the Netherlands, the Rasmussen Index is very close to 1.0, i.e. the linkages of the R\&D sector are on average for "domestic production and import", while for "domestic production" they are much smaller due to the small domestic interrelatedness of sectors. In Germany, we observe a stable Rasmussen Index with no big differences between "domestic production and import" and "domestic production". Overall, it shows that the crisis rather improved the interrelatedness of the R\&D sector compared to the average of the national economies. The power of dispersion index remains relatively stable over time (Germany, Netherlands, Finland) or the index even slightly increases (France, Austria).

\section{Summary and discussion}

Empirically, nothing is known so far about the impact of the behavior of the R\&D sector under conditions of an economic crisis on the total economy. Still, several European economies used public R\&D spending in order to counteract the deep recession of the year 2008/2009. Some literature has dealt with the evaluation of these $R \& D$ programs as a means to counteract the 
crisis. This paper contributes to the literature by offering insights into the effects that the crisis has had on the R\&D sector's linkages and internal technological structure itself. Since stabilization policy translates through backward linkages, the insights provided here should add to policy maker's understanding and future policy design.

The results of the analysis suggest that we cannot reject our hypothesis of the specific behavior of the R\&D sector in the case of the severe economic downturn and its stabilizing impact on the total economy. Although the interrelatedness of the R\&D sector, expressed in the size and trend of backward multipliers, changed in different directions in the year of the economic crisis and followed different trends in the year after in the European economies under review, the size of fluctuations of the backward multipliers is, however, very small (below $1 \%$ ) in all countries under investigation. If we look at multipliers for "domestic production", the changes are even smaller than for "domestic production and imports". This indicates that any crisis effect rather stems from supplier relations with other countries than from domestic supply chains.

We can draw the overall conclusion that there is stability in the structural relations of the R\&D sector under conditions of economic crisis. This holds true even though there are some technological changes within the R\&D sector as expressed by the analysis of input coefficients. The crisis hit the overall production in all economies, which could be shown by the analysis of value added, but the R\&D sector differed in the majority of countries under review.

The methodical approach that we use in this paper has of course some drawbacks. It is, first of all, a static model. Dynamic effects are not covered. However, since we run a comparative analysis of possible structural changes of the R\&D sector, and not an estimation of output and employment effects, the use of a static model is still reasonable.

The central objective of this paper is to analyze whether the sudden economic downturn has shaken the structural linkages of the R\&D sector in technology oriented European economies. The empirical study is a short term oriented analysis, which is limited by the observation in years during and around the crisis, that is, 2008, 2009, and 2010. A wider time horizon of observation has not been possible because statistically harmonized and methodically suitable (commodity by commodity) input output tables have not been accessible so far. An analysis for longer time periods after the crisis would allow insights about a longer term structural effect. This will be subject to further investigations when further harmonized input output datasets become available. In addition, spillover effects deriving from cross-border supplier relations, which have not been subject of the empirical analysis here, remain for further research.

We know that different economic structures and inter-sectoral linkages induce different effects of an R\&D investment. The real impact depends on the economic structures behind. In this context, a policy lesson to learn from our findings is that even in a deep economic downturn, the structural relations of the R\&D sector remain relatively stable. This holds true especially for the linkages of the $R \& D$ sector in the domestic economy. The latter is a particularly positive message for policy makers because fiscal policy tools are typically installed to stabilize the domestic economy. Thus, besides the positive long-term effects of $\mathrm{R} \& \mathrm{D}$, well documented in the literature, the structural stability of the $R \& D$ sector during an economic crisis makes this sector a recommendable target for fiscal policy programs. . 
Acknowledgements: We greatly acknowledge comments and suggestions of the participants of scientific conferences and workshops, in particular the International Input Output Workshop in Osnabrueck/Germany 2016, the Meeting of the Committee of Evolutionary Economics of the Verein für Socialpolitik in Hannover/Germany 2016 and the International April Conference at Higher School of Economics Moscow 2016. Furthermore, the paper benefited strongly from comments and suggestions of three anonymous referees who we would like to thank. 


\section{References}

Aghion, P.; Askenazy, P.; Berman, N.; Cette, G.; Eymard, L. (2012): Credit Constraints and the Cyclicality of R\&D Investment: Evidence from France, Journal of the European Economic Association, Paris: Banque de France.

Alecke, B.; Mitze, T.; Reinkowski, J.; Untied, G. (2011) Does Firm Size make a Difference? Analysing the Effectiveness of R\&D Subsidies in East Germany. German Economic Review, 13(2), 174-195.

Andreosso-O'Callaghan, B; Yue, G. (2004): Intersectoral Linkages and Key Sectors in China, 1987-1997. In: Asian Economic Journal, Vol. 12, No. 3, pp. 165-183.

Archibugi, D.; Filippetti, A. (2011): Is the Economic Crisis Impairing Convergence in Innovation Performance across Europe? In: Journal of Common Market Studies, Vol. 49, 11531182.

Archibugi, D.; Filippetti, A. (2012): Innovation and economic crisis. Lessons and prospects from the economic crisis. London, New York: Routledge.

Archibugi, D.; Filippetti, A.; Frenz, M. (2013a): The impact of the economic crisis on innovation: Evidence from Europe. In: Technological Forecasting and Social Change, 80, $1247-$ 1260.

Archibugi, D.; Filippetti, A.; Frenz, M. (2013b): Economic crisis and innovation: Is destruction prevailing over accumulation?, In: Reserach Policy, 42, 303-314.

Aristei, D.; Sterlacchini, A.; Venturini, F. (2015): Effectiveness of R\&D subsidies during the crisis: firm-level evidence across EU countries. In: Journal Economics of Innovation and New Technology, http://dx.doi.org/10.1080/10438599.2016.1249543

Barlevy, G. (2007): On the Cyclicality of Research and Development, American Economic Review, 97, 1131-1164.

Bayoumia, T., Coea, D. T., Helpman, E. (1999): R\&D spillovers and global growth, Journal of International Economics, Vol. 47, 2, pp. 399-428.

Bems, R.; Johnson, R.; Yi, K.-M. (2013): The Great Trade Collapse. In: Annual Review of Economics, 2013, vol. 5, issue 1, pages 375-400.

Brautzsch, H.-U.; Günther, J.; Loose, B.; Ludwig, U.; Nulsch, N. (2015): Can R\&D Subsidies Counteract the Economic Crisis? - Macroeconomic Effects in Germany, in: Research Policy, Vol. 44, 623-633.

David, P.A.; Hall, B.H.; Toole, A.A. (2000): Is public R\&D a complement or substitute for private R\&D? A review of the econometric evidence. Research Policy 29, 497-529.

DIW (1967): Auswirkungen der beiden Konjunkturprogramme auf die einzelnen Wirtschaftszweige, Wochenbericht des DIW, Nr. 34/1967, 203-206.

Devinney, T.M. (1990): New products over the business cycle, Journal of Product Innovation Management, 7, 261-273.

Eaton, J.; Kortum, S.; Neiman, B.; Romalis, J. (2010): Trade and the Global Recession, NBER Working Paper 16666. 
Eurostat (2013): European system of accounts. ESA 2010. Luxembourg: Publications Office of the European Union.

Fagerberg, J.; Srholec, M. (2016): Global dynamics, capabilities and the crisis. In: Journal of Evolutionary Economics, 26, 765-784.

Freund, C. (2009): The Trade Response to Global Downturns: Historical Evidence, Policy Research Working Paper No. 5015, Washington: World Bank.

Gramke, K., Böhmer, M., Fischer, D. (2009): Schlüsselbranchen für ein Konjunkturpaket. Basel: Prognos.

Grossman, G.M., Helpman, E. (1992): Innovation and Growth in the Global Economy. The MIT Press: Cambridge.

Hall, B. H.; Moncada-Paternò-Castello, P.; Montresor, S.; Vezzani, A. (2016): Financing constraints, R\&D investments and innovative performances: new empirical evidence at the firm level for Europe. In: Economics of Innovation and New Technology, Vol. 25, No. 3, 183-196.

Harhoff, D. (1998): Are There Financing Constraints for R\&D and Investment in German Manufacturing Firms, Annales d'Économie et de Statistique, 49/50, 421-456.

He, D.; Zhang, Z.; Zhang, W. (2009): How large will be the effect of China's fiscal stimulus package on output and employment? In: Pacific Economic Review, 14, 730-744.

Hirschman, A. O. (1968): The Political Economy of Import-Substituting Industrialization in Latin America. In: The Quarterly Journal of Economics, Vol. 82, No. 1, 1-32.

Hud, M.; Hussinger, K. (2015): The impact of R\&D subsidies during the crisis. In: Research Policy, Vol. 44, 1844-1855.

Kancs, d.; Siliverstovs, B. (2016): R\&D and non-linear productivity growth. In: Research Policy, Vol. 45, 634-646.

Kang, T.; Baek, C.; Lee, J.-D. (2017): The persistency and volatility of the firm R \& D investment: Revisited from the perspective of technological capability. In: Research Policy, 46, pp. $1570-1579$.

Kraines, S.; Yoshida, Y. (2004): Process System Modelling of Production Technology Alternatives using Input- Output Tables with Sector Specific Units. In: Economic Systems Research, Vol. 16 , Iss. 1, pp. 21-32.

Kuckshinrichs, W., T. Kronenberg, P. Hansen (2010): Das CO2-Gebäudesanierungsprogramm der KfW: Klimaschutz, Konjunktur- und Budgeteffekt, Wirtschaftsdienst, 90 (9), 616-623.

Kumar, S.; Das, S. (2015): Sector Analysis on Make in India. In: Indian Journal of Applied Research, Vol 5, No 11, pp. 143-153.

Levchenko, A. A.; Lewis, T.; Tesar, L. L (2010): The Collapse of International Trade during the 2008-09 Crisis: In Search of the Smoking Gun. In: IMF Economic Review, Volume 58, Issue 2, pp 214-253.

OECD (2009): Policy Responses to the Economic Crisis: Investing in Innovation for LongTerm Growth. Paris: OECD. 
OECD (2012): Innovation in the crisis and beyond. In: OECD Science, Technology, and Industry Outlook.

Östblom, G. (1992): Technological Change, Projection of the Technology Matrix and the Hypothesis of Negative Coefficient Changes: Parametric and Non-parametric Tests with Swedish Input-Output Data. In: Economic Systems Research, 4:3, pp. 235-244.

Rafferty, M.; Funk, M. (2004): Demand shocks and firm-financed R\&D expenditures. In: Applied Economics, 36, 1529-1536.

Rasmussen, P. N. (1956). Studies in Intersectoral Relations. Amsterdam, North-Holland P.C.

Reyher, L. (1968): Über die Auswirkungen der beiden Konjunkturprogramme von 1967 auf das Arbeitsvolumen, Mittteilungen aus der Arbeitsmarkt- und Berufsforschung, 3/68, 144-147.

Richter, J. (1995): Technologie in Input Output Tabellen - Abbildung von Produktionsverhältnissen oder statistische Artefakte? In: Schnabel, H. (ed.): Technologieverflechtung und Strukturwandel. Tübingen: Mohr. pp. 179-196.

Schumpeter, J. A. (1911): The Theory of Economic Development. Harvard University Press. Cambridge.

Schwartz, M.; Peglow, F.; Fritsch, M.; Günther, J. (2012): What Drives Innovation Output from Subsidized R\&D Cooperation? Project-level Evidence from Germany, Technovation, 32 (6), 358-369.

Shleifer, A. (1986): Implementation Cycles. In: Journal of Political Economy, 94, 1163-1190.

Spitznagel, E. (1976): Anwendung des erweiterten Input-Output-Modells auf das „Programm zur Stärkung von Bau- und anderen Investitionen", Mittteilungen aus der Arbeitsmarkt- und Berufsforschung, 3/76, 350-362.

Sun, X., Wang, Y., Li, M. (2016): The influences of different R\&D types on productivity growth in OECD countries. In: Technology Analysis \& Strategic Management, 28:6, 651-663.

Ten Raa, T. (2007) The Extraction of Technical Coefficients from Input and Output Data, in: Economic Systems Research, 19 (4), 453-459.

Yuan, C.; Liu, S.; Xie, N. (2010): The impact on chinese economic growth and energy consumption of the Global Financial Crisis: An input-output analysis. In: Energy, 35, $1805-$ 1812 . 


\section{Annex}

Annex 1: R\&D multipliers for gross value added and income

\begin{tabular}{|c|c|c|c|}
\hline & \multicolumn{3}{|c|}{ R\&D multipliers for "domestic production" } \\
\hline & \multicolumn{3}{|c|}{ Gross value added } \\
\hline & 2008 & 2009 & 2010 \\
\hline Germany & 1.5942 & 1.4951 & 1.5170 \\
\hline France & 2.0359 & 2.0201 & 2.0311 \\
\hline Austria & 1.4016 & 1.4168 & 1.4768 \\
\hline Netherlands & 1.2436 & 1.2703 & 1.2555 \\
\hline \multirow{3}{*}{ Finland } & 1.3294 & 1.3225 & 1.3401 \\
\hline & \multicolumn{3}{|l|}{ Income } \\
\hline & 2008 & 2009 & 2010 \\
\hline Germany & 1.4555 & 1.3736 & 1.4127 \\
\hline France & 1.6850 & 1.6864 & 1.6781 \\
\hline Austria & 1.2460 & 1.2452 & 1.2656 \\
\hline Netherlands & 1.1354 & 1.1355 & 1.1306 \\
\hline \multirow[t]{4}{*}{ Finland } & 1.1816 & 1.1930 & 1.1995 \\
\hline & \multicolumn{3}{|c|}{ R\&D multipliers for "domestic production and import" } \\
\hline & \multicolumn{3}{|c|}{ Gross value added } \\
\hline & 2008 & 2009 & 2010 \\
\hline Germany & 1.7726 & 1.6450 & 1.6883 \\
\hline France & 2.3809 & 2.3300 & 2.3762 \\
\hline Austria & 1.8266 & 1.8713 & 2.0004 \\
\hline Netherlands & 1.9279 & 1.9807 & 1.9749 \\
\hline \multirow[t]{3}{*}{ Finland } & 1.5596 & 1.5317 & 1.5529 \\
\hline & \multicolumn{3}{|l|}{ Income } \\
\hline & 2008 & 2009 & 2010 \\
\hline Germany & 1.5990 & 1.4984 & 1.5590 \\
\hline France & 1.9341 & 1.9134 & 1.9256 \\
\hline Austria & 1.5441 & 1.5600 & 1.5975 \\
\hline Netherlands & 1.6304 & 1.6409 & 1.6434 \\
\hline Finland & 1.3349 & 1.3436 & 1.3475 \\
\hline
\end{tabular}

